\title{
Meningkatkan Hemoglobin pada Ibu Hamil Trimester III dengan Rebusan Bunga Rosella
}

\author{
Rifi Wulandari \\ Jurusan D4 Kebidanan Poltekkes Kemenkes Bengkulu \\ Email korespondensi: rifiwulandari4@gmail.com
}

Article Info

Article history:

Submitted: 2020-06-12

Accepted: 2020-08-31

Published: 2020-09-6

Keywords:

Rosella Extract; Hemoglobin Level; Pregnant; Fe Tablet;
ABSTRACT

Anemia during pregnancy is one of the most common disorders in pregnant women in Indonesia. Rosella (Hibiscus sabdariffa) is considered able to increase the hemoglobin levels in pregnant mothers. To analyze the effect of Rosella flower on the increase of Hemoglobin level in pregnant women receiving $\mathrm{Fe}$ tablet. This study was a quasi-experiment with a pretestposttest control group design. 32 participants were selected using accidental sampling, which assigned in the experiment and control group. All samples were pregnant women in the third trimester and receiving iron tablets. Independent t-test and paired t-test were used for data analysis. The result indicated that there was an increase in hemoglobin levels in both the experiment and the control group. The mean increase of hemoglobin levels in the control group was $0.59 \mathrm{gr}$ and in the experiment group was 1.11 . The hemoglobin levels in the experiment group were higher than the levels in the control group. Independent t-test obtained a $p$-value of 0.241 indicating that there wasn't a significant mean difference of hemoglobin levels between the control group and the treatment group. The consumption of rosella combined with $\mathrm{Fe}$ tablet showed a significant increase of hemoglobin levels compared to pregnant women. Therefore, it is suggested for midwives to use the result of this research as evidence-practice through counseling for pregnant mothers about the utilization of rosella that can increase hemoglobin levels in pregnant.

\section{ABSTRAK}

Kata kunci:

Ekstrak Rosella; Kadar Hemoglobin; Ibu Hamil; Tablet Fe;
Anemia selama kehamilan adalah salah satu gangguan yang paling umum pada wanita hamil di Indonesia. Rosella (Hibiscus sabdariffa) dianggap mampu meningkatkan kadar hemoglobin pada ibu hamil. Tujuan penelitian ini adalah untuk menganalisis pengaruh bunga Rosella terhadap perubahan Hemoglobin pada ibu hamil yang mengkonsumsi tablet Fe. Penelitian ini adalah eksperimen semu dengan desain kelompok kontrol pretest-posttest. 32 Responden dipilih menggunakan accidental sampling, yang ditetapkan dalam eksperimen dan kelompok kontrol. Semua sampel adalah wanita hamil pada trimester ketiga dan menerima tablet zat besi. Uji hipotesis menggunakan Independent t-test dan paired t-test. Hasil penelitian menunjukan ada peningkatan hemoglobin pada kelompok eksperimen dan kontrol. Peningkatan rata-rata kadar hemoglobin pada kelompok kontrol adalah $0,59 \mathrm{gr}$ dan pada kelompok eksperimen adalah 1,11gr. Tingkat hemoglobin pada kelompok eksperimen lebih tinggi daripada tingkat pada kelompok kontrol. Independent t-test diperoleh nilai-p 0,241 yang menunjukkan bahwa tidak ada perbedaan yang signifikan dari tingkat hemoglobin antara kelompok kontrol dan kelompok perlakuan. Konsumsi ekstrak rosella yang dikombinasikan dengan tablet $\mathrm{Fe}$ menunjukkan peningkatan kadar hemoglobin yang signifikan pada ibu hamil. Oleh karena itu, disarankan bagi bidan untuk menggunakan hasil penelitian ini sebagai bukti praktik melalui penyuluhan untuk ibu hamil tentang pemanfaatan rosella yang dapat meningkatkan kadar hemoglobin pada wanita hamil. 


\section{PENDAHULUAN}

Menurut World Health Organization (WHO) Anemia merupakan masalah gizi yang mempengaruhi jutaan orang di negara-negara berkembang dan tetap menjadi tantangan besar bagi kesehatan manusia. Prevalensi anemia diperkirakan 9 persen di negara-negara maju, sedangkan di negara berkembang prevalensinya 43 persen. Anak-anak dan wanita usia subur (WUS) adalah kelompok yang paling berisiko, dengan perkiraan prevalensi anemia pada balita sebesar 47 persen, pada wanita hamil sebesar 42 persen, dan pada wanita yang tidak hamil usia 15-49 tahun sebesar 30 persen. WHO menargetkan penurunan prevalensi anemia pada WUS sebesar 50 persen pada tahun 2025. ${ }^{1}$

Berdasarkan hasil Riset Kesehatan Dasar (Riskesdas) tahun 2018, prevalensi anemia pada ibu hamil di Indonesia sebesar $48,9 \%$, yaitu ibu hamil dengan kadar $\mathrm{Hb}$ kurang dari 11,0 gram/dl, dengan proporsi yang hampir sama antara di kawasan perkotaan $(36,4 \%)$ dan perdesaan $(37,8 \%)$. Meskipun pemerintah sudah melakukan program penanggulangan anemia pada ibu hamil yaitu dengan memberikan 90 tablet Fe kepada ibu hamil selama periode kehamilan dengan tujuan menurunkan angka anemia ibu hamil, tetapi kejadian anemia masih tinggi. ${ }^{2}$

Data kesehatan propinsi bengkulu tahun 2018 ditemukan anemia gizi besi pada ibu hamil sebesar $45 \% .{ }^{3}$ Kasus anemia gizi besi pada ibu hamil di kota Bengkulu tahun 2015 sebanyak 168 kasus, tahun 2016 sebanyak 279 kasus, tahun 2017 sebanyak 1.398 dan tahun 2018 di temukan anemia gizi besi pada ibu hamil sebanyak 1.162 kasus, yang terdiri dari 20 puskesmas di kota Bengkulu. Menurut Dinas Kesehatan Kota Bengkulu kejadian anemia tertinggi Kota Bengkulu tahun 2018 adalah di Puskesmas Sawah Lebar 39,6 \%, Puskesmas Padang Serai 35,8 \% dan Puskesmas Ratu Agung 23,1\%.4-7

Anemia adalah suatu kondisi dimana jumlah sel darah merah tidak mencukupi untuk memenuhi kebutuhan fisiologis tubuh. Wanita usia subur dan wanita hamil berisiko tinggi mengalami anemia. ${ }^{8}$ Anemia mempengaruhi sepertiga dari populasi dunia dan berkontribusi pada peningkatan morbiditas dan mortalitas, penurunan produktivitas kerja, dan gangguan perkembangan saraf. ${ }^{9}$ Anemia merupakan penurunan kemampuan darah untuk membawa oksigen. Akibat dari penurunan jumlah sel darah merah atau berkurangnya konsentrasi hemoglobin dalam sirkulasi darah, yaitu konsentrasi hemoglobin $(\mathrm{Hb})<11 \mathrm{gr} / \mathrm{dl}$ pada trimester I dan III, dan $<10 \mathrm{gr} / \mathrm{dl}$ pada trimester II. Seiring dengan hemodilusi yang terjadi pada usia 24 minggu dan memuncak pada kehamilan 28-32 minggu menyebabkan kadar $\mathrm{Hb}$ dalam tubuh ibu semakin menurun. ${ }^{10}$ lbu hamil anemia akan meningkatkan risiko terjadinya abortus, lahir premature, BBLR, lahir mati, kematian perinatal, partus lama dan perdarahan pasca persalinan ${ }^{11}$

Program suplementasi zat besi merupakan upaya yang telah dilakukan pemerintah Indonesia untuk mencegah anemia dalam kehamilan yang diberikan dalam bentuk pil zat besi ferro sulfat $200 \mathrm{mg}$ setiap hari selama 90 hari pada trimester III kehamilan tetapi angka anemia dalam kehamilan masih tinggi. Hal ini karena terdapat beberapa factor yang mempermudah dan menghambat absorbs zat besi dalam tubuh. Konsumsi buah-buahan yang mengandung vitamin $\mathrm{C}$ sangat berperan dalam absorbs zat besi melalui peningkatan absorbs non heme hingga empat kali lipat. Mekanisme ini termasuk mereduksi ferri menjadi bentuk ferro dalam lambung yang mudah diserap ${ }^{11,12}$ 
Pemberian tablet besi bersamaan dengan zat gizi mikro lain lebih efektif dalam meningkatkan status besi dibandingkan dengan hanya memberikan suplementasi besi dalam bentuk dosis tunggal. Oleh karena itu untuk meningkatkan penyerapan besi dalam tubuh perlu diberikan dengan kombinasi mikronutrien vitamin $C$, hal ini karena zat besi yang efektif dan efesien adalah zat besi dalam bentuk ferro sehingga mudah larut. Vitamin $\mathrm{C}$ dapat mengubah suasana asam di lambung dengan mengubah ferri menjadi ferro yang mudah larut sehingga mudah diabsorbsi. Salah satu sumber vitamin $\mathrm{C}$ adalah bunga rosella ${ }^{11}$

Rosella (Hibiscus sabdariffa) adalah salah satunya herbal tumbuh paling mudah di banyak daerah. Umumnya tanaman ini dikenal memiliki manfaat sebagai obat antihipertensi, diabetes, dan antimitosis. Tanaman ini juga memiliki yang kandungan tertinggi mineral (Fe) dan vitamin $\mathrm{C}$ di antara tanaman lain, seperti bayam, daun singkong, dan daun Katuk. Di dalam 100gr kelopak bunga Rosella memiliki zat besi sebanyak 8,98 mg dan vitamin C sebanyak 244,4 mg. ${ }^{13}$

Penelitian ini bertujuan untuk mengetahui tingkat perubahan hemoglobin pada ibu hamil yang mengkonsumsi tablet Fe dengan rebusan bunga rosella dan ibu hamil mengkonsumsi Fe tidak dengan rebusan bunga rosella.

\section{METODE PENELITIAN}

Desai penelitian yang digunakan adalah Quasi eksperimen dengan menggunakan pendekatan pretest and posttest non-equivalent control group

Populasi dalam penelitian ini adalah ibu hamil Trimester III di Puskesmas Ratu Agung periode Januari 2020. Jumlah sampel dalam penelitian sebanyak 16 orang untuk masing-masing kelompok. Untuk mengantisipasi drop out ditambah $10 \%$ sampel dari masing-masing kelompok, jadi masing-masing kelompok 16 responden sehingga di dapat jumlah sampel 32 responden. Teknik pengambilan sampel dalam penelitian ini adalah accidental sampling yaitu dengan mengambil kasus atau responden yang kebetulan ada atau tersedia disuatu tempat sesuai dengan konteks penelitian. Instrumen dalam penelitian ini adalah lembar kuesioner, lembar persetujuan menjadi responden.

Analisis data dilakukan secara bertahap yaitu analisis univariat dan bivariat. Analisis univariat dilakukan untuk mengidentifikasikan karakteristik ibu hamil dan kadar hemoglobin ibu hamil sebelum dan setelah perlakuan pada kelompok intervensi dan kontrol. Analisis bivariat digunakan untuk melihat pengaruh variabel independen dengan variabel dependen. Analisis dalam penelitian ini menggunakan uji t-dependen. Untuk melihat perubahan tingkat hemoglobin ibu hamil antara kelompok intrevensi (ibu hamil yang mengkonsumsi rebusan bunga rosella) dengan kelompok kontrol (ibu hamil yang tidak mengkonsumsi rebusan bunga rosella) dilakukan Uji $t$-Independen.

\section{HASIL PENELITIAN}

Tabel 1 Distribusi Frekuensi Karakteristik Ibu hamil (Usia, Paritas, dan Asupan Gizi)

\begin{tabular}{lccrr}
\hline \multirow{2}{*}{ Variabel } & \multicolumn{3}{c}{ Kontrol } & \multicolumn{3}{c}{ Intervensi } \\
\cline { 2 - 5 } & Jumlah & $\%$ & Jumlah & $\%$ \\
\cline { 2 - 5 } $\begin{array}{l}\text { Usia } \\
<20 \text { dan }>35 \text { th }\end{array}$ & 8 & 50,0 & 1 & 6.2 \\
$20-35$ th & 8 & 50,0 & 15 & 93.8 \\
\hline
\end{tabular}




\begin{tabular}{lcccc}
\hline \multirow{2}{*}{ Variabel } & \multicolumn{5}{c}{ Kelompok } \\
\cline { 2 - 5 } & Jumlah & $\%$ & Jumlah & $\%$ \\
\cline { 2 - 5 } $\begin{array}{c}\text { Paritas } \\
>3\end{array}$ & 2 & 12.5 & 1 & 6.2 \\
$\leq 3$ & 14 & 87.5 & 15 & 93.8 \\
\hline $\begin{array}{c}\text { Asupan Gizi } \\
\quad \text { Tidak tercukupi }\end{array} \quad$ Tercukupi & 6 & 37.5 & 6 & 37.5 \\
$\quad$ Sumber: Data primer, 2020 & 10 & 62.5 & 10 & 62.5 \\
\hline$\quad$ & & &
\end{tabular}

Berdasarkan tabel 1, dapat dilihat hasil karakteristik responden menunjukkan bahwa pada kelompok ibu hamil yang mengkonsumsi Fe sebagian besar $(50 \%)$ ibu hamil berisiko tinggi, sebagian besar ibu hamil multipara $(87.5 \%)$ dan asupan gizi sebagian besar tercukupi (62.5\%). Sedangkan pada kelompok yang diberikan bunga rosella sebagian besar (93.8\%) merupakan ibu hamil yang tidak berisiko tinggi, sebagian besar merupakan ibu multipara(93.8\%) dan asupan gizi sebagian besar tercukupi $(62,5 \%)$

Tabel 2 Perbedaan Hemoglobin sebelum dan sesudah pemberian bunga rosella pada ibu hamil yang mengkonsumsi tablet $\mathrm{Fe}$

\begin{tabular}{|c|c|c|c|c|}
\hline HB & Mean & Beda Mean & SD & Nilai $p$ \\
\hline \multicolumn{5}{|l|}{ Kelompok intervensi } \\
\hline Sebelum Intervensi & 11.33 & \multirow{2}{*}{1.11} & 0.936 & \multirow{2}{*}{$<0.001$} \\
\hline Setelah intervensi & 12.44 & & 0.940 & \\
\hline \multicolumn{5}{|l|}{ Kelompok Kontrol } \\
\hline Sebelum Intervensi & 11.45 & 0.59 & 1.061 & \multirow{2}{*}{$<0.001$} \\
\hline Setelah intervensi & 12.04 & & 0.923 & \\
\hline
\end{tabular}

Sumber: Data primer, 2020

Berdasarkan tabel 2, diketahui bahwa pada kelompok ibu hamil sebelum diberikan bunga rosella rata-rata kadar $\mathrm{Hb}$ adalah $11.33 \mathrm{gr} / \mathrm{dl}$ dan setelah diberikan bunga rosella $12.44 \mathrm{gr} / \mathrm{dl}$. beda mean dari kedua kelompok yaitu $1,11 \mathrm{gr} / \mathrm{dl}$. pada kelompok ibu hamil sebelum diberikan tablet $\mathrm{Fe}$ rata-rata kadar $\mathrm{Hb}$ adalah $11.45 \mathrm{gr} / \mathrm{dl}$ dan setelah diberikan tablet fe adalah $12.04 \mathrm{gr} / \mathrm{dl}$. sehingga beda mean dari kedua kelompok yaitu $0.59 \mathrm{gr} / \mathrm{dl}$.

Berdasarkan tabel 2, dapat disimpulkan bahwa ada pengaruh pemberian bunga rosella + fe dengan rata-rata kadar $\mathrm{Hb}$ sebelum dan sesudah intervensi yang dapat dilihat uji statistik nilai $p<0.001$ dengan beda mean 1.11 , hal ini berarti penambahan bunga rosella berpengaruh terhadap peningkatan kadar hemoglobin pada ibu hamil yang mengkonsumsi tablet $\mathrm{Fe}$. Pada kelompok kontrol yang hanya diberi tablet fe saja hasil rata-rata kadar $\mathrm{Hb}$ sebelum dan sesudah intervensi dapat dilihat uji statistik nilai $p<0.001$ dengan beda mean 0.59 , hal ini berarti pemberian tablet Fe saja berpengaruh terhadap peningkatan kadar hemoglobin pada ibu hamil. 
Tabel 3. Efektivitas kelompok bunga rosella dan kelompok Fe terhadap Hemoglobin pada ibu hamil

\begin{tabular}{lccccc}
\hline Kelompok & Mean & $\begin{array}{l}\text { Beda } \\
\text { Mean }\end{array}$ & N & SD & $\begin{array}{l}\text { P } \\
\text { value }\end{array}$ \\
\hline Tablet Fe & 12.04 & & 16 & 0.923 & \\
$\begin{array}{l}\text { Tablet Fe dan bunga } \\
\text { rosela }\end{array}$ & 12.43 & 0.39 & 16 & 0.940 & 0.241 \\
\hline
\end{tabular}

Sumber: Data primer, 2020

Berdasarkan tabel 3, dapat dilihat bahwa tidak ada perbedaan kadar hemoglobin antara ibu hamil yang mengkonsumsi tablet $\mathrm{Fe}+$ bunga rosella dengan ibu hamil yang mengkuonsumsi tablet fe saja, karena nilai p pada kedua kelompok adalah 0,241 . Hal ini berarti pada kedua kelompok sama-sama efektif meningkatkan kadar hemoglobin pada ibu hamil.

\section{PEMBAHASAN}

Variabel Asupan gizi sebagian besar responden sebagian besar mempunyai asupan gizi yang tercukupi. Tetapi masih ditemukan ibu yang asupan gizinya tidak tercukupi, jika dilihat dari yang mengalami asupan gizi tidak tercukupi tersebut adalah ibu hamil yang anemia. Sejalan juga dengan penelitian Sumiyarsih, dkk (2018) menyatakan bahwa asupan gizi sangat berpengaruh terhadap hemoglobin ibu hamil trimester III karena disetiap keluarga diharapkan mampu memenuhi kebutuhan pangan dengan jumlah yang cukup maupun mutu gizinya, ibu hamil yang asupan gizinya kurang dapat mengakibatkan daya tahan tubuh ibunya kurang sehingga dapat menimbulkan penyakit. ${ }^{14}$

Hasil penelitian menunjukkan bahwa pemberian ekstrak rosella yang dikombinasikan dengan tablet Fe meningkatkan kadar hemoglobin ibu hamil yang mengalami anemia. Hal ini membuktikan bahwa ekstrak rosella efektif untuk manusia khususnya pada ibu hamil pada penelitian ini, sebagaimana penelitian sebelumnya mengungkapkan bahwa ekstrak rosella berpengaruh nyata dalam meningkatkan jumlah eritrosit dan kadar hemoglobin $(\mathrm{Hb})$ pada tikus putih (Rattus). ${ }^{15}$

Hasil penelitian ini menunjukkan ada peningkatan kadar hemoglobin sebesar $1,11 \mathrm{gr} / \mathrm{dl}$ setelah intervensi. Pemberian bunga rosella yang mempunyai vitamin $\mathrm{C}$ yang tinggi dapat membantu penyerapan Fe pada ibu hamil. Kandungan vitamin $\mathrm{C}$ yang tinggi pada rosella sangat membantu penyerapan. Hal ini didukung oleh penelitian sebelumnya bahwa terdapat peningkatan kadar $\mathrm{Hb}$, serum ferritin, bobot badan dan BMI pada kelompok yang diberi vitamin $\mathrm{C}$ dibandingkan dengan kelompok kontrol, ${ }^{16}$ Vitamin $\mathrm{C}$ sangat membantu penyerapan besi non heme dengan mereduksi besi ferri menjadi ferro dalam usus halus sehingga mudah diabsorpsi. ${ }^{17}$

Penelitian ini menunjukkan bahwa ada pengaruh signifikan penambahan bunga rosella terhadap perubahan tingkat hemoglobin pada ibu hamil yang mengkonsumsi Fe dengan nilai $p=0.241$ dan pada kelompok kontrol ada pengaruh signifikan juga terhadap perubahan tingkat hemoglobin pada ibu hamil. Hal ini berarti secara uji statistic pada kedua kelompok sama-sama efektif meningkatkan kadar hemoglobin pada ibu hamil. Tetapi pada uji klinis pada kedua kelompok, kelompok intervensi lebih efektif yaitu dengan diberi tambahan bunga rosella dari pada hanya diberikan tablet 
Fe saja.

Hasil penelitian Nisa R (2017) dalam penelitian efektivitas ekstrak rosella terhadap perubahan tingkat hemoglobin pada ibu hamil yang mengkonsumsi $\mathrm{Fe}$ menemukan bahwa ada peningkatan kadar hemoglobin yang signifikan bila mengkonsumsi ekstrak rosella yang dikombinasikan dengan tablet Fe dibandingkan dengan konsumsi tablet Fe saja dengan nilai $P-0,00(<0,05) \cdot{ }^{18}$ Penelitian Kristian dan Prastiwi (2019) di Malang, dimana seluruh responden dalam penelitian tersebut mengalami anemia. Setelah dilakukan intervensi, pada kelompok pemberian teh rosella dan tablet $\mathrm{Fe}$ responden dengan anemia berkurang $60 \%$, sedangkan pada kelompok Fe saja hanya berkurang $33,4 \%$ saja. Ini menunjukan pemberian seduhan teh rosella kering dapat meningkatkan Kadar hemoglobin. ${ }^{19}$

Dalam upaya mencegah anemia gizi pada ibu hamil, pemerintah melakukan pemberian suplementasi TTD (Tablet Tambah Darah) dengan dosis pemberian sebanyak 1 tablet (60 mg Elemental Iron dan 0,25 $\mathrm{mg}$ asam folat) berturut-turut minimal 90 hari selama masa kehamilan, selain itu perlu dilakukan upaya lain dalam penanggulangan dan pencegahan anemia ibu hamil dengan cara peningkatan keanekaragaman konsumsi bahan makanan sumber zat besi, kesadaran ibu hamil untuk mengonsumsi tablet besi, dan peran serta suami dalam mendorong ibu hamil mengonsumsi tablet besi. ${ }^{20}$

\section{SIMPULAN DAN SARAN}

Penelitian ini menyimpulkan bahwa pemberian table Fe dan Bunga Rosella efektif dalam meningkatkan Hemoglobin 0.39 dibandingkan pada ibu hamil yang mengkonsumsi tablet Fe saja. Penelitian ini menyarankan agar ibu mengonsumsi ekstrak bunga rosella untuk menambah hemoglobin.

\section{DAFTAR PUSTAKA}

1. World Health Organization. The global Prevalence of Anaemia in 2011. Who. Geneva: World Health Organization; 2011. 1-48 p.

2. Kementerian Kesehatan R.I. Laporan Riset Kesehatan Dasar Tahun 2018. Jakarta: Kementerian Kesehatan R.I.; 2018.

3. Dinas Kesehatan Propinsi Bengkulu. Profil Kesehatan Propinsi Bengkulu. Bengkulu; 2019.

4. Dinas Kesehatan Kota Bengkulu. Profil Kesehatan Kota Bengkulu Tahun 2015. Bengkulu; 2016.

5. Dinas Kesehatan Kota Bengkulu. Profil Kesehatan Kota Bengkulu Tahun 2016. Bengkulu; 2017.

6. Dinas Kesehatan Kota Bengkulu. Profil Kesehatan Kota Bengkulu Tahun 2017. Bengkulu; 2018.

7. Dinas Kesehatan Kota Bengkulu. Profil Kesehatan Kota Bengkulu Tahun 2018. Bengkulu; 2019.

8. Gautam S, Min H, Kim H, Jeong H-S. Determining factors for the prevalence of anemia in women of reproductive age in Nepal: Evidence from recent national survey data. Kabir R, editor. PLoS One [Internet]. 2019 Jun 12;14(6). Available from: https://dx.plos.org/10.1371/journal.pone.0218288

9. Chaparro CM, Suchdev PS. Anemia Epidemiology, Pathophysiology, and Etiology in low- and middle- income Countries. Ann N Y Acad Sci [Internet]. 2019 Apr 22; Available from: https://onlinelibrary. wiley.com/doi/abs/10.1111/nyas.14092

10. Husin F. Asuhan Kehamilan Berbasis Bukti. Jakarta: Sagung Seto; 2015.

11. Wirawan S, Khairul L, Nuriyansari B, ristrini. Pengaruh Pemberian Tablet Besi dan 
Tablet Besi Plus Vitamin C terhadap Kadar Hemoglobin Ibu Hamil (Effect of Vitamin C and Tablets Fe on Haemoglobin Levels Against Pregnant Women). Bul Penelit Sist Kesehat. 2015;18(2):285-92.

12. Sediaoetama. Ilmu Gizi Untuk Mahasiswa dan Profesi. 1st ed. Jakarta: Dian Rakyat; 2000.

13. Haidar Z. Si Cantik Rosella. Jakarta: Edumania; 2016.

14. Sumiyarsi I, Nugraheni A, Mulyani S, Cahyanto EB. Faktor-Faktor yang Mempengaruhi Hemoglobin Ibu Hamil Trimester III. PLACENTUM J IIm Kesehat dan Apl [Internet]. 2018 Aug 30;6(2):20. Available from: https://jurnal.uns.ac.id/placentum/article/view/22836

15. Munawaroh S. Pengaruh Ekstrak Kelopak Rosella terhadap Peningkatan Jumlah Eritrosit dan Kadar Hemoglobin dalam Tikus Putih Anemia. Universitas Islam Negeri Malang; 2009.

16. Asiyah S, Rahayu DE, Isnaeni WDN. Perbandingan Efek Suplementasi Tablet Tambah Darah Dengan Dan Tanpa Vitamin C Terhadap Kadar Hemoglobin Pada Ibu Hamil Dengan Usiakehamilan 16-32 Minggu Di Desa Keniten Kecamatan Mojo Kabupaten Kediri. J IImu Kesehat [Internet]. 2017 Jun 13;3(1):76. Available from: https://ejurnaladhkdr.com/index.php/jik/article/view/49

17. Dewi SSS, Batubara NS. Pengaruh Zat Besi dan Vitamin C terhadap Perubahan Kadar Hemoglobin Ibu Hamil. Siklus J Res Midwifery Politek Tegal [Internet]. 2019 Jan $31 ; 8(1): 56$. Available http://ejournal.poltektegal.ac.id/index.php/siklus/article/view/1209

18. Nisa R, Soejoenoes A, Wahyuni S. Effect of Roselle (Hibiscus sabdariffa) on Changes in Hemoglobin Levels in Pregnant Women with Anemia Taking Iron Supplement. Belitung Nurs J [Internet]. 2017 Dec 28;3(6):771-7. Available from: https://belitungraya.org/BRP/index.php/bnj/article/view/305

19. Kristiana AS, Prastiwi ED. Effectiveness Of Dry Rosela Tea Improving Haemoglobin Levels In Young women In The City of Malang. J Wiyata. 2019;6(1):6-12.

20. Suastira, Sumiaty, Ansar. Konsumsi Pangan Sumber Zat Besi dan Asam Folat dengan Anemia pada Ibu Hamil di Puskesmas Tawaeli. J Bidan Cerdas [Internet]. 2018;1(1):915. Available from: http://jurnal.poltekkespalu.ac.id/index.php/JBC/article/view/40 